\title{
Temporal-spatial distribution and implications of peraluminous granites in Tibet
}

\author{
Liao Zhongli†*, Mo Xuanxueł, Pan Guitang†, Zhu Dicheng†, Wang Liquan†, J iang Xinsheng† and Zhao Zhidan‡ \\ † Chengdu Institute of Geology and Mineral Resources, Chengdu, Sichuan, 610082, CHINA \\ ¥ China University of Geosciences, Beijing,100083, CHINA \\ *To whom correspondence should be addressed.E-mail: liaozl@cugb.edu.cn
}

There are many outcrops of peraluminous granites in QinghaiTibet plateau. It is an important format of stronger magmatic activity. The Himalayan and Gandise belts are the famous for research bases of peraluminous granites. In the Himalayan belt, muscovite granite provide petrological evidence that India subducted northward below the Tibetan Continent (Deng Jinfu et al. 1994). Based on summary of past research data, the goal of present paper is to study temporal-spatial distribution and basic character of peraluminous granites in Tibet, and to discuss the implication of peraluminous granites to Eurasia-India collision and the uplift of Tibetan Plateau.

The Temporal-Spatial Distributions of peraluminous granites in Tibet The peraluminous granites in Tibet, which are approximately distributed E-W, belong to Gandise-Nyainqentanglha and Himalayan tectono-magmatic provinces. There are 58 major peraluminous granitic bodies in southern Tibet, which cover an area of about $3800 \mathrm{~km}^{2}$ and distributed in seven belts (Figure 1): Baingoin-Baxoila Ling Belt, Coqen-Xainza belt, south Gandise belt, Yarlung Zangpo suture, Lhagoi Kangri belt, northern Himalayas belt and high Himalayas belt. Most of the granites occur to the south of Bangong Co-Gerze-Amdo-Nu Jiang suture and tectonically in the Gandise-Himalayas tectonic region. The intrusive bodies greatly vary in scale ranging from the minimum of less than $1 \mathrm{~km}^{2}$ to the maximum of $1780 \mathrm{~km}^{2}$. W-E oriented Kula Kargari granite is the biggest pluton in the studied region.
The periods of peraluminous granites

The authors analyzed 704 vended chronological data on granite during past two decades (Zhang 1981, Sorkhabi and Stump 1993) and discoverd that the magmatic activity became gradually stronger and reached peak in Miocene. The authors also revealed that the magmatic activity of peraluminous granites have similar trend (Figure 2).

182 chronological data of peraluminous granites (Sorkhabi and Stump 1993, Tong Jingsong, 2003) show differences in different belts, mainly in 10-20 Ma (Figure 2). The magmatic activities of the peraluminous granites began in the Early Jurassic and gradually reached a peak in the Miocene. The isotopic ages vary in different granite belt but are concentrated in the period between 10-20 Ma.

The granites in northern Himalayas were formed in Miocene during the late period of Himalayan orogeny. The granites in the three belts north of Yarlung Zangpo suture were formed in the Jurassic, Cretaceous, and Eocene-Miocene, respectively with different activity peak of 90-140 Ma (i.e., the Cretaceous period) in addition to the Miocene peak. Zircon U$\mathrm{Pb}$ isotopic dating of two samples by SHRIMP shows that the Luoza granite formed in early Cretaceous with an age of $116 \pm 43$ $\mathrm{Ma}$. The upper intercepton of zircon U-Pb concordia is $2475 \pm 13$ $\mathrm{Ma}$, showing old basement in Gandise belt.

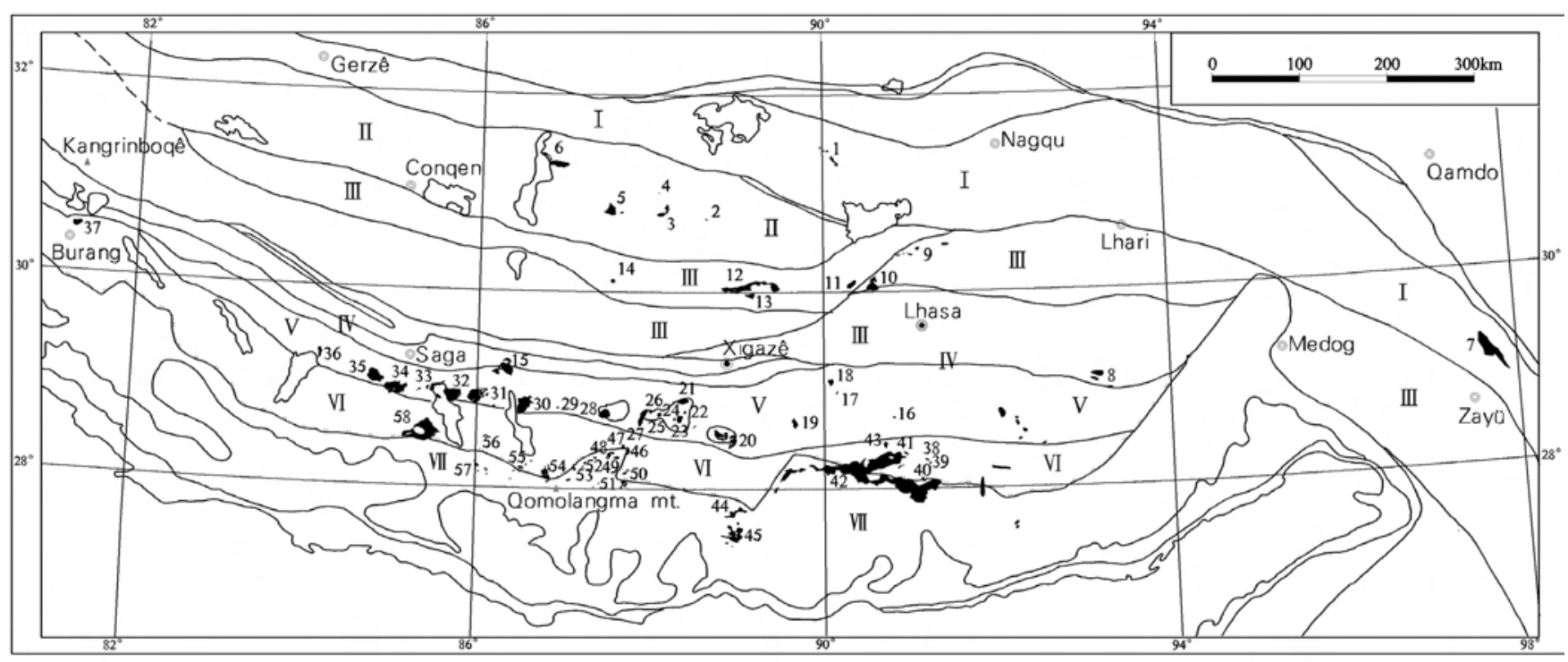

FIGURE 1. The distributions of peraluminous granites in Tibet I- Baingoin-Baxoila Ling belt II- Cogen-Xainza belt III- South Gandise belt IV- Yarlung Zangpo suture V- Lhagoi Kangri belt VI- northern Himalayan belt VII- High Himalayan belt; 1 58 - rock number 


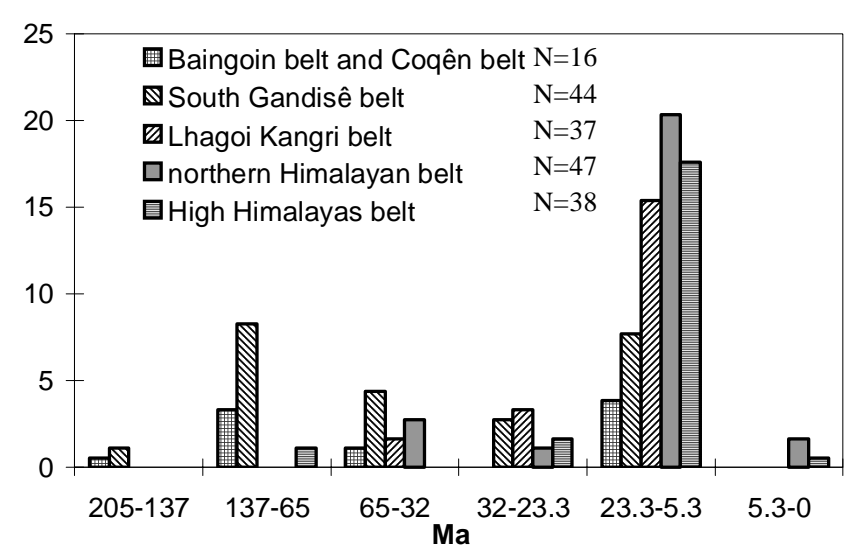

FIGURE 2. Histogram of isotope ages peraluminous granites from Tibet

\section{Scale of magmatic activity}

There are obvious differences in different period of magmatic activity scale. In these cases, magmatic activity was mainly concentrated in Miocene ( $<23.3 \mathrm{Ma}$ ) and in Eocene (56.5-32 Ma). The area of Miocene peraluminous granites covers $77.29 \%$ of total area of peraluminous granites from Tibet (Figure 3).

\section{Implications}

InTibet, study of peraluminous granites was affluent in research contents about Eurasia-India collision and the uplift of Tibetan Plateau. And it provides petrological evidence that India subducted beneath the Tibetan continent.

Despite the fact that the study become serious about the present lithospheric structure and facts were constantly discovered, some basic characteristics are to be accepted by everyone (Mo et al. 1995): (1) generally, the earth's crust of Qinghai-Tibet plateau is very deep (in average of about $70 \mathrm{~km}$ ), and the lithosphere was comparatively thin (in average of about $150 \mathrm{~km}$ ); (2) obvious differences in the lithosphere structure exist in Qinghai-Tibet plateau everywhere (inhomogeneity); and (3) it shows low velocity layer inside crust southward from Nyainqentanglha, north Tibet ubiquity crust and mantle mix belt. The present lithosphere structure of Qinghai-Tibet plateau is the final result of integrated geological, geophysical, geochemical processes. Based on this case, we can discuss the magmatic event of Tibet peraluminous granites which will contribute to the form and evolution of Qinghai-Tibet plateau.

Since $200 \mathrm{Ma}$, the activity of peraluminous granites become gradually stronger, and is mainly concentrated in 3 peaks: 137$96 \mathrm{Ma}, 65-32 \mathrm{Ma}$ and 20-10 Ma. It is comparable to 3 peaks of volcanic activities: 115-75 Ma, 60-50 Ma and <20 Ma. The first and the second tectonic-magmatic events are concentrated in Gandise belt, and form a volcano-granitic basement of more than $2000 \mathrm{~km}$ length and $300000 \mathrm{~km}^{2}$ area. Gandise belt was the center of magmatic activity and hot center of Qinghai-Tibet plateau in this period. The third tectonic-magmatic event brings on peraluminous granites because of inner crust movement and regulate in Himalaya. The three magmatic events correspond to three tectonic events: subduction of Neotethyan ocean, India-

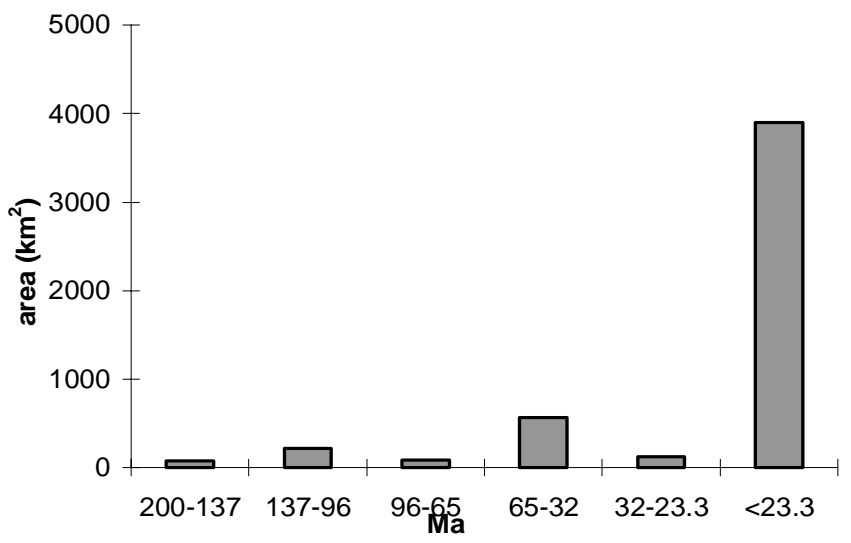

FIGURE 3. Histogram of age-area for peraluminous granites from Tibet

Eurasia collsion and intracontinental subduction and plateau uplift.

The characteristics of lithosphere tectonic evolution can be reflected by the petrological and geochemical feature of the south Tibetan peraluminous granite as follows: the peraluminous granite in Late Triassic and Early Jurassic (208-157 Ma) may be the result of the early subduction event of the Bangong co Nujiang Ocean; the granite in the Late Jurassic-Early Cretaceous(157-97 Ma) represents the subduction and collisional event of the Bangong co-Nujiang Ocean; the granite in Late Cretaceous(97-65 Ma) represents the initial subduction and collision of Yarlung Zangpo Ocean; the granite in Eocene(65-40 $\mathrm{Ma}$ ) represents the main collision stage, when the Yarlung Zangpo belt was still under the stage of subduction-collision, forming a serial of crust source granite. Oligocene and Miocene indicate violent intracontinental subduction stage and form a series of thrust slipend ductile shear zones. Since Miocene, the quick thinning of plateau lithosphere and delamination occurred followed by thickening of the lithosphere and the crust.

\section{Acknowledgments}

This study is financially supported by the National Keystone Basic Research Program of China (No. 2002CB412609) and the Key Laboratory of Lithospheric Tectonics and Exploration, China University of Geosciences, Ministry of Education, China (No. 2003003).

\section{References}

Deng J, Zhao H, Lai S et al. 1994. Generation of muscovite/two-mica granite and intracontinental subduction. Earth Science - Journal of China University of Geosciences 19(2): 139-147 (in Chinese with English abstract)

Mo X, Zhao C, Guo T et al. 1995. Some problems study for tectonic evolution and magmatic hot event in Qinghai-Tibet plateau. Unpublished internal report (in Chinese)

ZhangY, Dai T and Hong A. 1981. Isotopic geochronology of granitoid rocks in southern Tibet plateau. Geochimica 1981 (1) : 8-18 (in Chinese with English abstract)

Sorkhabi RB and E Stump. 1993. Rise of the Himalaya: A Geochronologic Approach. GSA Today 3(4): 87-92

Tong J, Zhong H, Xia J et al. 2003. Geochemical features and tectonic setting of peraluminous granite in the Lhozagarea. southern Tibet. Geological bulletin of China 22(5): 308-318 (in Chinese with English abstract) 